\title{
DEMOCRATIC LEADERSHIP IS THE ESSENCE OF BETTER PRODUCTIVITY \& EMPLOYEE MOTIVATION
}

\author{
MANOJ KUMAR SATPATHY \\ Research Scholar, Faculty of Management, Sri Shankaracharya Group of Institution,
}

SSTC Bhilai, Chhattisgarh, India

\begin{abstract}
The democratic leadership style works best in creative businesses, design firms and corporations driven by research and development. The participatory leadership style is also well-suited for educational institutions with collaborative environments.

The democratic leadership style also works best in inventive organizations, structure firms and partnerships driven by innovative work. The participatory leadership style is additionally appropriate for instructive foundations with communitarian conditions.

Privately owned businesses, instructive foundations and not-for-profit associations in the extension mode are appropriate for the democratic/participative leadership style since it energizes the joint effort. Participatory leadership rewards achievement and encourages a collegial domain.

Democratic pioneers are centered on achieving objectives. Efficiency is the way to embracing this leadership style. To be effective, democratic pioneers must have profitable groups that meet desires.

KEYWORDS: Leadership Style, Business, Democratic \& Rewards
\end{abstract}

Received: Feb 25, 2019; Accepted: Mar 15, 2019; Published: Apr 22, 2019; Paper Id.: IJHRMRJUN20194

\section{INTRODUCTION}

Democratic leadership, also known as participative leadership or shared leadership is a type of leadership style in which members of the group take a more participative role in the decision-making process. This type of leadership can apply to any organization, from private businesses to schools to government.

Everyone is given the opportunity to participate, ideas are exchanged freely, and discussion is encouraged. While the democratic process tends to focus on group equality and the free flow of ideas, the leader of the group is still there to offer guidance and control. The democratic leader is charged with deciding who is in the group and who gets to contribute to the decisions that are made.

Researchers have found that the democratic leadership style is one of the most effective types and leads to higher productivity, better contributions from group members, and increased group morale.

\section{DEMOCRATIC LEADERSHIP}

It's hard to envision democratic pioneers achieving their objectives without direct cooperation from others. Investment is vital to all fruitful democratic ventures. This incorporates 
- Attentive constituents in a congressional region

- Concerned guardians of understudies at a school

- Active individuals from a non-profit association

- Engaged workers at a succeeding organization

\section{WHAT IS THE MEANING OF DEMOCRATIC LEADERSHIP?}

One of the clearest meanings of democratic leadership originates from John Gastil. His 1994 article, "A Definition and Illustration of Democratic Leadership" for the Human Relations diary stays pertinent to private industry and the free market.

Gastil, a teacher at Penn State University, has composed widely about jury determination and democratic cooperation in the considerations procedure. His brief meaning of democratic leadership clarifies that it is thoughtfully particular from places of power.

Gastil's meaning of democratic leadership,

"Circulating duty among the participation, engaging gathering individuals, and supporting the collective choice's creation procedure."

\section{CASE IN POINT: APPLE}

Apple was a fruitful organization from 1976 to 1985, preceding which it nearly bombed in the mid-1990s. At that point it turned out to be colossally efficient again - on the same grounds that it wavered.

At the end of the day, Apple had a dream. Apple lost its vision. Apple recaptured its vision.

That is uncommon.

In the mid-1990s Gateway, Microsoft, Sun Microsystems and different organizations allegedly focused on Apple as an obtainable target. Now, huge numbers of those brands have vanished. However, Apple still endures.

Mac endures on the grounds that Steve Jobs figured out. He began as a charming/free enterprise pioneer; turned into a democratic/participative pioneer and Apple took off. When the Apple's governing body asked for his acquiescence, at that point he turned into an authoritative leader.

When he was back in Apple over 10 years later, Jobs consolidated a few leadership styles and included democratic/participative to his collection. He bought in other experienced pioneers and depended on them to exceed expectations. Jobs empowered his lead planner Jonathon Ive, and coached Tim Cook, the present CEO. He let them settle issues using their own key choices.

That is the reason Apple endures.

\section{INSTANCES OF DEMOCRATIC/PARTICIPATIVE LEADERSHIP}

Every single effective pioneer is a self-completing individual with heaps of fearlessness. They assume liability for their activities, they bolster their groups, and they don't rationalize disappointments. 
Among U.S. presidents, there are numerous instances of men who brought the democratic/participative leadership style to the Oval Office. The vast majority of these presidents showed qualities that mirrored an assortment of leadership styles.

U.S. presidents with democratic leadership characteristics,

- George Washington: Unlike telling troops amid the American Revolution, Washington was eminently democratic while managing the U.S. government. He hinted at his democratic leadership style by naming the chosen leaders to his staff. His choice was not to serve a third term and exemplified a democratic head who realized when to pass the light.

- Thomas Jefferson: President Jefferson was both a tyrant and democratic pioneer. As essential creator of the U.S. Affirmation of Independence in 1776, Jefferson left no opportunity to convey his equivocalness about his commitment to vote based system: "We hold these certainties to act naturally obvious, that all men are made equivalent." In 1803, he imperiously skirted Congress to assist the Louisiana Purchase for \$15 million.

- Abraham Lincoln: Often thought as the encapsulation of a democratic pioneer, Lincoln was totalitarian in his choices all through his administration. In spite of the fact that his character and standards were democratic in nature, Lincoln was an absolutist chief as President out of need. The Civil War requested conclusiveness.

- Dwight D. Eisenhower: He was far progressively democratic in his way to deal with crushing Germany amid WWII than his subordinate, Gen. George C. Patton, Eisenhower was a strategist and accord developer. Eisenhower was an exemplary military officer who established free enterprise and democratic/participative leadership styles as President.

- John F. Kennedy: A charming pioneer on the most fundamental level, Kennedy showed qualities of free enterprise and democratic leadership styles. His initiating of the Apollo Space Program is a case of JFK's free enterprise style. In different cases, he indicated authoritative leadership propensities, for example, his fast choices amid the Cuban Missile Crisis.

- Jimmy Carter: A previous maritime authority, Carter exemplified both the characteristics and traps of the democratic/participative leadership style as President. He encircled himself with some accomplished staff, yet he regularly conceded to unproductive subordinates, when acting definitively would have been a superior decision.

\section{DEMOCRATIC LEADERSHIP IN BUSINESS}

Business endeavors and different associations include various specialists, so they are appropriate to the democratic/participative leadership process. Regardless of whether it's a CEO or an undertaking supervisor, democratic pioneers can be viable in business on the off chance that they encircle themselves with experienced players.

The participatory style works best with specialists who know their occupations and complete their duties under negligible supervision. This is valid for,

- $\quad$ Biotech R\&D divisions

- Housing building locales

- Universities 
- Information innovation organizations

However in private organizations and government offices following a strict system or a high turnover of representatives, the despotic leadership style is increasingly popular. Indeed, even inside these situations, however, divisions exist that work best under a democratic/participative leadership style.

\section{Examples}

- Pharmaceutical industry: Pharmaceutical organizations have instructed scientific experts who function admirably in collective groups on improvement ventures. Such organizations additionally require totalitarian pioneers who oversee subordinates in mechanized mechanical production system tasks. They rebel systems and tight resilience that don't loan themselves to a democratic/participative leadership style.

- Hospitals and labs: Hospitals and medicinal services testing offices require a mix of leadership styles. In Medical/ clinic organization, from faculty and bookkeeping divisions to offices, support and protection; requires totalitarian leadership to guarantee consistency and responsibility. All the while, doctors work cooperatively under democratic/participative pioneers. Likewise it's the same with attendants, who utilize both despotic and democratic leadership styles to complete group capacities and individual obligation.

- High-tech firms: The innovation business offers endless instances of organizations that are appropriate for the democratic/participative leadership style. Many are new companies with building and programming improvement groups that work cooperatively under democratic pioneers. In fruitful cases, these organizations advance from free enterprise new companies to democratic-driven endeavours to develop dictatorial organizations.

\section{COMPANIES THAT REFLECT DEMOCRATIC LEADERSHIP PRINCIPLES}

Most successful companies evolve, and their leaders display a mix of leadership styles. They have autocratic leaders who run manufacturing, quality control and distribution divisions along with R\&D teams spearheaded by democratic/participative leaders.

Examples of companies where democratic/participative leadership works,

- Google: Founders, Sergey Brin and Larry Page built up their Internet web crawler while seeking after their doctorates at Stanford. Subsequent to getting initial finance, they accomplished something out of the ordinary. Brin and Page pursued the guidance of experienced business people and enlisted Eric Schmidt to kick off their organization. Joining a mix of despotic, free enterprise and democratic leadership styles, the Novell and Sun official brought understanding into Google's hole. The three quickly started exploring experienced ability to set up democratic/participative groups. Today, Google remains moderately democratic in its way to deal with product improvement under CEO Page.

- Genentech: A pioneer in the revelation and improvement of limitation compounds to create organic medications, Genentech was begun by Robert Swanson and Herbert Boyer. They confronted rivalry for money related assets and ability when they propelled the organization in 1976. Recombinant DNA innovation was a secret to everyone except a couple of forward-looking scientists and scientific experts. The method to Genentech's prosperity was imparting democratic/participative leadership to pull in those researchers. In spite of the fact that it's presently claimed by Roche, Genentech stays on the main edge by mixing democratic R\&D with absolutist assembling 
leadership styles.

- Mayo Clinic: A charitable association with notoriety for being a standout amongst the most cutting edge medical services and investigative offices on the planet, the Mayo Clinic innovates with democratic/participative leadership. Established by Dr. William Mayo and his family, the emergency clinic, medicinal services and research office draws in the absolute and most splendid personalities in the restorative field since it gives them chances to work cooperatively among peers on democratic groups. Despite the fact that the procedures required in the therapeutic research industry frequently require a very absolutist methodology, medicinal services associations like the Mayo Clinic can't prevail without democratic/participative pioneers.

- Amazon.com: Amazon began its operations, selling books. The organization succeeded by grasping each of the three of Lewin's leadership models. It began as a free enterprise organization, with Jeff Bezos as definite mediator of every single key choice. He selected a ton of veteran PC developers from close-by programming organizations and immediately executed a democratic/participative leadership show. Today, Amazon sells everything believable, including cloud administrations and huge information security stockpiling. Amazon is fundamentally despotic on account of its pledge to convenient client administration. At its center, nonetheless, the organization holds its democratic qualities among C-suite administrators, division heads and task chiefs.

\section{FAMOUS DEMOCRATIC LEADERS}

The democratic/participative leadership style works best in creative businesses, design firms and corporations driven by research and development. The participatory leadership style is also well-suited for educational institutions with collaborative environments.

Examples of leaders who exhibit democratic leadership style,

The democratic leadership style works best in inventive organizations, structure firms and partnerships driven by innovative work. The participatory leadership style is additionally appropriate for instructive foundations with communitarian conditions.

\section{INSTANCES OF PIONEERS WHO DISPLAY DEMOCRATIC/ PARTICIPATIVE LEADERSHIP STYLE}

- Indra Nooyi: Nooyi, the CEO and executive of PepsiCo, has a charmed presence among workers. She looks into the individual existences of workers and has a dream of the organization's future. Nooyi made news when she sent letters to the guardians giving them direct reports to tell them how pleased they ought to be of their official grown-up/youngsters. When one enrolled was unsure about joining the organization, Forbes magazine reports, Nooyi called the hopeful's mother and in this way handled the official. She has additionally made fanatics out of financial specialists keen on divestitures and acquisitions, for example, Tropicana, Quaker Oats and Gatorade.

- Bill George: George was a senior official at Honeywell and Litton Industries before joining Medtronic as CEO. Presently a teacher at Harvard Business School, George says he felt hamstrung by the bureaucratic procedures before joining Medtronic. In spite of the fact that he recognizes the need of imperious techniques in organizations with tight assembling controls, George acclaims Medtronic's creative way to deal with social insurance advancements. Noted for its heart stents and mechanical heart valves, Medtronic would not have flourished under 
George's tutelage from 1991 to 2001 had he not been committed to the standards of shared research endeavours, prepared into the democratic/participative leadership style.

- Tommy Lasorda: A fruitful baseball pitcher before training, Lasorda fortified with his players. As administrator of the Los Angeles Dodgers from 1976 to 1996, Lasorda won two World Series titles, four National League flags and eight division titles. Thought about a player's mentor, Lasorda's choice to give Kirk Gibson a chance to squeeze hit amid the 1988 World Series against the Oakland A's remaining parts a standout amongst the most essential crossroads in baseball history. Most chiefs would not have sent a harmed player to the plate against a pro pitcher. Lasorda did as such in light of the fact that he confided in his player's judgment and his own senses. Both are signs of a fruitful democratic/participative pioneer in real life. Gibson hit a grand slam and helped the Dodgers win the arrangement.

- Ginni Rometty: As CEO of IBM since 2012, Rometty has shown a systematic way to deal with overseeing and a democratic/participative leadership style. She has settled on the intense choices expected of IBM CEOs, for example, selling its beneficial however abating server business and diminishing staff. She has likewise dedicated assets to IBM's enormous information endeavours. IBM is joining forces with human services organizations, government undertakings and web based life firms to use its qualities in psychological processing.

- Muhtar Kent: Known as a democratic/participative pioneer, Kent is CEO and director of the board at Coca-Cola. $\mathrm{He}$ is noted for his focus on the contribution from others on key choices. Kent has a comprehensive style that mirrors his promise to decent variety and is as dedicated to improving administrative procedures and assembling efficiencies as he is to cooperation. He stirred his way up the professional bureaucracy, to some degree, by multiplying Coca-Cola's packaging activities. As CEO, Kent assembled synergistic supervisory crews to address moderating deals, development and handled difficulties from worldwide contenders, mirroring a mix of totalitarian and democratic styles.

A noteworthy trademark among democratic/participative pioneers is comprehensiveness. Democratic pioneers look for cooperation from a wide scope of individuals, including ladies.

\section{DEMOCRATIC LEADERSHIP QUOTES}

These pioneers are known as large trailblazers and solid colleagues. Huge numbers of them mixed diverse leadership styles or developed to receive the attributes of democratic pioneers. Here are a few citations that uncover their commitment to democratic and participatory leadership.

Thomas Aquinas: "If the most elevated point of a commander were to protect his ship, he would keep it in port until the end of time."

Jeff Bezos: "I unequivocally trust that preachers improve items. They care more. For an evangelist, it's not just about the business. There must be a business, and the business needs to bode well. In any case, that is not why you do it. You do it since you have something significant that spurs you."

Dwight D. Eisenhower: "Leadership is the craft of getting another person to accomplish something you need done in light of the fact that he needs to do it."

David Packard: "Go for broke. Make huge inquiries. Try not to be hesitant to commit errors. In the event that 
you don't commit errors, you're not coming to sufficiently far."

Steve Jobs: "One of the keys to Apple will be Apple's an unbelievably shared organization."

Ginny Rometty: "I ask everybody's conclusion when they don't talk up. And afterward, when they have a sentiment, I'll get some information about it."

Mahatma Gandhi: "Genuine difference is a decent indication of advancement."

Tommy Lasorda: "I think overseeing resembles grasping a pigeon. Press excessively hard and you execute it, not sufficiently hard and it takes off."

William J. Mayo: "Master, convey me from the man who never commits an error. And furthermore from the man who commits a similar error twice."

Bill George: "You'd sit in a conference and state, 'Is this item adequate to go to patients - so 100 percent of all patients who get it will have their lives improved? On the off chance that it's not, we will need to return to the planning phase."

Thomas Jefferson: "Deferral is desirable over mistake."

Jerry Yang: "Positively Yahoo wouldn't exist without the kind of condition that Stanford offered us to make it."

Sergey Brin: "Taking care of enormous issues is simpler than taking care of little issues."

Tip O'Neill: "It's simpler to keep running for office than to run the workplace."

Jimmy Carter: "The experience of vote based system resembles the experience of life itself - continually changing, boundless in its assortment, here and there violent and even more profitable for having been tried by affliction."

\section{DEMOCRATIC LEADERSHIP CASE STUDY: TWITTER}

It should not shock anyone that an organization dedicated to momentarily getting the message out about everything without exception in 140 characters or less has a reputation for being community oriented.

Twitter, which has seen fits and fists since its establishment about 10 years prior, has a mutual leadership style that's nothing but the best. Established by Jack Dorsey, Evan Williams, Biz Stone and Noah Glass, Twitter started life in 2006 as a democratic/participative undertaking.

It remains so today.

Every one of Twitter's prime supporters had an alternate vision of what the organization ought to turn into. That vision went from an insubordinate underground area to a sort of brand focal station where any organization or individual could get the message out about their items and goals and also great many devotees.

Dorsey, who has been designated "the genuine center fellow benefactor," never faltered from his vision of Twitter as a content informing administration that would change the world as we probably are aware of it - or as the youthful Dorsey knew it when he began coding Twitter two decades prior.

Dorsey is both a democratic and a free enterprise pioneer. A quintessential multitasker, his family and friends know him as a utilitarian trendy person with design sense. He hates all waste and loves his hair styles and grew up tuning 
in to $\mathrm{C}$-band radio. He dispatches of crisis work force reacting to wrongdoings and fires, false cautions and fatal occasions.

In spite of the fact that Dorsey has returned to the job of official director, Twitter stays moderate and community oriented.

Both Dorsey and Twitter speak to the new influx of democratic/participative leadership in business. Like Dorsey, Twitter has taken quite a while to discover its compass.

Twitter's quality?

Quickness is basic in the new universe of online life.

Democratic/participative leadership style necessities

Democratic leadership has numerous names. They include,

- $\quad$ Participative leadership

- $\quad$ Shared leadership

- Open-book board

- $\quad$ Participative basic leadership

- Democratic board style

The democratic/participative leadership style has a few likenesses to free enterprise leadership, yet there are additionally huge contrasts.

Free enterprise pioneers enable subordinates to choose how to finish their errands and undertakings, yet not to settle on association choices. Participative leadership not just acknowledges subordinates' remarks, thoughts and proposals; it likewise energizes their contribution on choices and techniques.

Both of these styles rely upon the pioneer having talented, instructed and experienced workers. Utilizing the democratic leadership style with unpracticed staff is an inconvenience except if the specialists have an uncommon instinct for what should be finished.

In any case, the greater part of the prominent democratic/participative pioneers since forever have succeeded on the grounds that they urged their staff to get engaged with the exchanges about major and minor choices.

\section{DEMOCRATIC LEADERS ARE HIGHLY RATIONAL}

Noted hierarchical therapist Bernard M. Bass concentrated Lewin's enormous three leadership styles: free enterprise, imperious and democratic. In "The Bass Handbook of Leadership," he called attention to effective pioneers ordinarily show numerous qualities from various leadership styles.

Bass, an Educator Emeritus at Binghamton University and establishing Executive of the Center for Leadership Studies in 2007, saw that democratic pioneers are authentic and normal in their way in dealing with critical thinking and assessing staff execution. He additionally saw that democratic pioneers "de-stressed social separation," while dictatorial pioneers displayed their higher social stature among subordinates.

Social standing is one of a few key qualifications among dictatorial and democratic pioneers. Albeit the two styles 
can be viable, imperious pioneers are tyrant since they regularly regulate inexperienced subordinates, or they're accused of preparing experienced individuals to perform new undertakings rapidly, for example, learning a creative program or receiving a refreshed quality-control process.

By correlation, democratic/participative pioneers are,

- Egalitarian types who feel comfortable rolling up their sleeves

- Team-oriented captains who view experienced staff as peers

- Consensus builders who like to mediate disagreements

- Flexible explorers who share decision-making with key staff

\section{PETER DRUCKER ON LEADERSHIP QUALITIES}

Diminish Drucker, prestigious administration specialist and top rated creator, wasn't enthusiastic about names. In any case, he comprehended the qualifications among various kinds of pioneers.

In one of his last meetings, Drucker talked about business morals with Forbes magazine. Drucker's guidance for administrators, especially democratic/participative pioneers, still seems to be valid.

Democratic pioneers are incredible multitaskers. As Drucker calls attention to, gainful pioneers are phenomenally practiced in light of the fact that they depend on specialists to make recommendations without giving up control of the basic leadership process.

In 2004, Drucker stated,

"Try not to take on things you don't put stock in that you yourself are bad at. Figure out how to state no. Compelling pioneers coordinate the target needs of their organization with the abstract abilities. Subsequently, they get a tremendous measure of things done quick."

\section{WHAT ARE THE CHARACTERISTICS OF DEMOCRATIC LEADERS?}

Democratic/participative pioneers share normal attributes with free enterprise pioneers, for example, appointing. The key qualification is their contribution in the basic leadership process.

Democratic pioneers don't just contract specialists to run divisions or ventures and after that hang tight for the outcomes. They embed themselves simultaneously and remain educated. They frequently depend vigorously on information; however they are not captives to measurements. They balance the impulses of experienced group pioneers with the substances of the commercial center.

They are issue solvers. In the event that there is no interest for an extraordinary thought, democratic pioneers will regularly pass on it. They go out on a limb, yet they realize when to cut their misfortunes. Democratic/participative pioneers are,

- Egalitarian

- $\quad$ Fair-minded

- Adaptive 
- Engaged

- Role models

- $\quad$ Forward-thinking

- $\quad$ Team-oriented

- Consensus builders

One of the key offering indicates about democratic leadership thought about different styles is that it functions admirably all through an association.

The absolutist leadership style, by examination, works inside specific offices however not really starting from the top. Tyrant leadership can be smothering and dispiriting on the off chance that it exists all through a whole association.

The democratic/participative style can exist at each dimension in certain organizations. This style can function admirably in an association that is centered on development, research and ability securing.

Privately owned businesses, instructive foundations and not-for-profit associations in extension mode are appropriate for the democratic/participative leadership style since it energizes joint effort. Participatory leadership rewards achievement and encourages a collegial domain.

Brilliant, skilled individuals love collegial situations. It's up to democratic/participative pioneers to select them, empower them and screen their advancement sufficiently only to guarantee profitability.

On the whole, chances are that there is one admonition to the participatory leadership style it is this: Too much accord building can prompt stagnation.

By the day's end, somebody needs to assume liability for the choices.

Effective democratic/participative pioneers own up and they settle on an official conclusion.

The best ones are readied. They realize when they're going to hit one out of the ballpark. They trust their groups; however they stay educated about work process advance all the time.

\section{PREFERENCES AND BURDENS OF DEMOCRATIC/PARTICIPATIVE LEADERSHIP}

In principle, the benefits of democratic leadership are evident to subordinates. The vast majority want to work inside a leadership structure that supports keen exchange and rewards community oriented procedures.

As a general rule, not everyone loans themselves to the democratic leadership style.

Administrators, board individuals, trustees and speculators have desires fixated on profitability. For them, the participative leadership style may appear to be unseemly.

In certain organizations and associations, where in-house procedures are profoundly centered, entirely controlled and regularly idealized, other leadership styles, such as dictatorial, are a superior fit.

It's dependent upon pioneers to decide the best style for working gatherings inside their organizations and establishments. Here are a few contemplations. 


\section{PROS IN DEMOCRATIC LEADERSHIP}

- Employees have increased job satisfaction and a sense of empowerment.

- Relationships are built on mutual trust between labor and management.

- Absenteeism is lower among employees with a stronger commitment to performance.

- Productivity increases as a result of a solutions-centric workforce that has input.

- Creativity and innovation increase among employees through team collaboration.

\section{CONS IN DEMOCRATIC LEADERSHIP}

- Leaders can become overly dependent on the expertise and experience of subordinates.

- Collaboration can consume valuable time, getting input from people who aren't in agreement.

- Fast, incisive decisions may be difficult or even impossible, resulting in missed deadlines.

- Relying on consensus from people who are misinformed or lack accurate data can be costly.

- Leaders can become burdened by the challenge of overseeing experts on collaborative teams.

\section{BENEFITS OF DEMOCRATIC LEADERSHIP}

The democratic style requires an extraordinary sort of pioneer, yet it additionally requires a unique gathering of members. Everybody must be ready for the participatory procedure. This requires an incredibly natural and attentive pioneer who acts definitively when clashes emerge among colleagues.

\section{CONCLUSIONS}

The best democratic leaders are great multi taskers. They are able to handle the challenge of working with experienced people on collaborative teams without losing sight of objectives or deadlines.

Democratic leaders are focused on accomplishing goals. Productivity is the key to adopting this leadership style. To be successful, democratic leaders must have productive teams that meet expectations.

\section{REFERENCES}

1. "Kurt Lewin: Groups, Experiential Learning And Action Research"

2. John Gastil, "A Definition and Illustration of Democratic Leadership"

3. "Kendra Cherry": Democratic Leadership 
